\title{
Management of the Quality of Services Provided in the Field of Healthcare of the Socio-Economic System
}

\author{
Arutyunova A.E. ${ }^{1, *}$ Smirnova E.V. ${ }^{1}$ Kashin V.A. ${ }^{2}$ \\ ${ }^{1}$ Kuban State Technological University, Krasnodar, 350000, Russia \\ ${ }^{2}$ Krasnodar Higher Military Aviation School named after the Hero of the Soviet Union A.K. Serova, Krasnodar, 350000 , \\ Russia \\ *Corresponding author. Email: aru-asya@yandex.ru
}

\begin{abstract}
The article is devoted to the issue of managing the quality of medical services provided to different segments of the population within the framework of one of the main goals of the state social policy of the Russian Federation. The study presents questions devoted to the development of a standardization and certification system in the field of healthcare to improve the quality of preventive, therapeutic and diagnostic measures in solving the problems of maintaining and improving the health of all segments of the population. An algorithm for studying the process of providing medical services based on quality indicators is considered. The problem of the influence of the organization of management and services on the assessment of the quality of services of medical and preventive institutions by the population is analyzed. The mechanism of forming a state order for the provision of high-tech specialized medical care to the population is presented. An assessment is made of the quality and effectiveness of medical services based on a comparison of actual actions and results achieved with established "standards" or "models". It is proposed to create a unified information space for organizing a quality management system in the field of medical services, which will create a data bank on the quality status in medical institutions. The introduction of modern information and analytical technology in the quality management system of medical services considered in three planes is proposed: the introduction of modern information and analytical technology, ensuring effective information interaction of all structures, providing relevant, reliable and complete data on the needs of medical care.
\end{abstract}

Keywords: quality of medical services, standard of care, standardization and certification, control,

healthcare system, pharmaceutical industry

\section{INTRODUCTION}

The most important factor determining the relevance of this article is the need to continue and develop modernization processes in the economy and management of the healthcare system at the state and municipal levels. A number of tasks that were taken into account in the national project "Health" and aimed at improving the quality of medical services and, naturally, the efficiency of the functioning of the healthcare system both at the state and municipal levels, and at the level of medical institutions and healthcare facilities, remain unsolved. Of the significant transformations in the healthcare sector, one can single out the increase in the provision of healthcare

facilities with high-tech diagnostic and treatment equipment,

as well as the solution of issues related to their informatization through the introduction of medical information and analytical systems (MIAS), which are aimed at automating the main medical processes of healthcare facilities [1] .

Nevertheless, the above technological and informational innovations in healthcare were not accompanied, in most cases, by an adequate modification of managerial and organizational technologies, which significantly reduces the effect of the measures taken to ensure the high quality and all kinds of accessibility of medical services of healthcare institutions.

In order to achieve the greatest efficiency and effectiveness of the functioning of healthcare institutions, it seems appropriate to introduce process-oriented quality management systems for medical services in healthcare institutions, which is a neoclassical synthesis of professional innovative management and modern information technologies in the healthcare system.

\section{RESEARCH METHODOLOGY}

The insufficiency of scientifically based methodological and practical developments in the field of process-oriented management of the quality of medical services in healthcare institutions, a small number of studies 
conducted on the issues under consideration, determined the relevance and applied importance of this article.

The aim of the study is the analysis of the state of the quality management system of services in the healthcare sector. The subject of the study is the organizational and economic relations that arise in the process of improving the efficiency of the quality of services provided by healthcare institutions in regional socio-economic systems. Research Methodology. In the framework of the aim and objectives of the study, the approach of a critical analysis of the scientific literature, regulatory documents on managing the quality of healthcare services in a market economy and practical experience in implementing assessments of the state of the healthcare sector in the regional socio-economic system is applied.

Today, research economists devote a large number of works to issues of quality management of services, in particular in the field of healthcare. Among the scientists who made a significant contribution to the study of the quality category and its assessment, the works of E. Deming, D. Juran, F. Crosby, G. Tagutti, A. Feighenbaum should be noted.

A study of scientific approaches to standardizing the activities of medical institutions and an analysis of the possibility of integrating standards in healthcare are presented in works of A. N. Vyalkov, V. B. Lomakin, A. A. Merkulov, O.V. Pushkarev.

\section{RESEARCH RESULTS}

The main goal of the social policy of the Russian Federation is to constantly increase the level and quality of life of the population, ensuring universal access to basic social services, first of all, quality medical care and social services.

Objectively, health is a real prerequisite for satisfying individual, collective and social material and spiritual needs. At the same time, the need to continue and develop modernization processes in the health care economy, envisaged in the framework of the priority national project "Health", federal and regional health development programs, as well as "Strategy 2020", remains urgent, since their implementation so far has not been able to significantly change the situation in the industry [4].

The provision of medical services has a positive effect. This is especially clearly demonstrated by the example of medical services related to the treatment of infectious diseases. In a broader sense, the external effect of medical services is expressed in increasing investment in health in the structure of human capital due to the impact of this type of service on the duration and quality of their consumer's participation in the development of society, its productivity and improving welfare.

Currently, in the framework of the state policy of the Russian Federation in the field of healthcare, active measures are being taken to improve the quality and accessibility of medical services.

However, the scientifically substantiated concept of "medical services" and "accessibility of medical services", as well as their socio-economic content, has not yet been clearly defined, despite the urgent need for this.

The quality of medical services is a multifaceted concept, and its provision requires the maximum consolidation of the creativity and practical experience of specialists. However, none of the legislative acts discloses the concept of the quality of medical services, which creates additional difficulties in realizing the rights to receive quality medical care.

The quality of medical services is a set of characteristics of medical care, reflecting its ability to meet the needs of different segments of the population.

The quality of medical services can be considered from the standpoint of their accessibility, safety, optimality and is evaluated in three areas:

- $\quad$ the structure (material and technical capabilities, human resources), which characterizes the conditions for the provision of medical services, but is not a guarantee of quality;

- $\quad$ the result (it depends both on the quality of the process of providing medical services, and on factors not related to the work of the doctor, that is, the severity of the patient, his age, features of the disease, etc.);

the process of providing medical services, i.e. medical process (through the influence on the process, you can affect the result).

Improving the quality of medical services should include three main areas:

- improvement of the material and technical base of medical institutions (including adequate financing of medical services);

- improving the results of medical care;

- continuous improvement of the quality of medical care.

Figure 1 shows an algorithm for studying the quality of medical services based on the use of quality indicators: standards, clinical protocols, recommendations.

Based on the essence and features of the concept and content of "medical service" as an action that brings benefits, customer satisfaction, its key characteristics, such as "quality" and "accessibility" of this type of service, determining the final result of their provision, are fixed.

"Accessibility of medical services" is expressed as the ability of a consumer of medical services to receive the necessary medical service of appropriate quality with the shortest possible time and resources.

Table 1 presents the essence and content of the criterion of "medical service". 


\begin{tabular}{|c|c|c|}
\hline \multicolumn{3}{|c|}{ Quality indicators of medical services } \\
\hline \multicolumn{3}{|c|}{$\downarrow$} \\
\hline \multicolumn{3}{|c|}{$\begin{array}{l}\text { The process of providing medical services to different segments of } \\
\text { the population }\end{array}$} \\
\hline \multicolumn{3}{|c|}{$\downarrow$} \\
\hline \multicolumn{3}{|c|}{$\begin{array}{l}\text { Information on the compliance or non-compliance of individual } \\
\text { elements of medical care with quality standards }\end{array}$} \\
\hline$\downarrow$ & & $\downarrow$ \\
\hline Single case & $\leftrightarrow$ & Set of cases \\
\hline$\downarrow$ & & $\downarrow$ \\
\hline $\begin{array}{c}\text { Examination of the quality of } \\
\text { medical care to clarify } \\
\text { deviations }\end{array}$ & & $\begin{array}{l}\text { General indicators of the } \\
\text { conformity or } \\
\text { inconsistency of the } \\
\text { medical process to different } \\
\text { segments of the population }\end{array}$ \\
\hline
\end{tabular}

Figure 1 Research algorithm for the process of providing medical services based on quality indicators

Table 1: The essence and content of the criterion of "medical service"

\begin{tabular}{|l|l|}
\hline \multicolumn{1}{|c|}{ Quality } & \multicolumn{1}{|c|}{ Accessibility } \\
\hline $\begin{array}{l}\text { Service characteristics of the provision of medical services } \\
\text { (comfort, design, waiting conditions) }\end{array}$ & $\begin{array}{l}\text { An opportunity to get access to a medical service } \\
\text { (specialist appointment, prescribed research/procedure) }\end{array}$ \\
\hline $\begin{array}{l}\text { The professionalism of medical personnel (qualification, } \\
\text { education, work experience, politeness in communication, } \\
\text { etc.) }\end{array}$ & $\begin{array}{l}\text { The opportunity with the minimum cost of all consumer } \\
\text { resources to get the necessary medical service }\end{array}$ \\
\hline $\begin{array}{l}\text { The speed and accuracy of diagnosis (the speed of the } \\
\text { prescribed procedures/analyzes and obtaining results, which } \\
\text { is achieved through clear coordination of the actions of } \\
\text { patients and communication of medical personnel with the } \\
\text { necessary departments of the healthcare organization) }\end{array}$ & $\begin{array}{l}\text { The territorial proximity of the medical institution to the } \\
\text { consumer of services, transport accessibility, the } \\
\text { availability of parking, the comfort of a treatment room, } \\
\text { etc. }\end{array}$ \\
\hline $\begin{array}{l}\text { Possibility of self-registration of a consumer of medical } \\
\text { services for an appointment with a specialist via } \\
\text { terminal/Internet }\end{array}$ & $\begin{array}{l}\text { The lack of a queue in a medical institution (at offices to } \\
\text { specialists, when contacting the registry, during medical } \\
\text { diagnostic operations, etc.) }\end{array}$ \\
\hline $\begin{array}{l}\text { The availability of prompt access for the consumer of } \\
\text { medical services to personal medical information via the }\end{array}$ & $\begin{array}{l}\text { The presence of a sufficient number of qualified } \\
\text { personnel, both of a wide profile and of narrow } \\
\text { Internet (when using an information and analytical system } \\
\text { specialists; as well as medical equipment in accordance } \\
\text { in a medical organization, electronic medical records of } \\
\text { patients, the patient has an electronic medical insurance } \\
\text { policy) }\end{array}$ \\
\hline
\end{tabular}

For a more perfect disclosure of the socio-economic nature of medical services, it seems rational to attract everyone to know the concept of the category of "external effects" (externalities), which is known in economic theory, which is associated with

the occurrence of costs or benefits for third parties as a result of the production, distribution or consumption of medical goods.

When analyzing the external effects of the provision of medical services, it should be noted that there is also a "humanistic" external effect, which suggests that patients in medical institutions can take part not only in protecting their own health or their relatives and friends but also in the health of the least protected layers of the national society of the country. This is manifested in a charitable (social in the broad sense) form of medical care for their own altruistic reasons.

The socio-economic nature and content of medical services are closely related to the criterion of human capital and investment in human capital. The capital of human health acts as a special resource, on the quantity and quality of which the realization of human capital and human potential depends, which makes up the economic and social development of the entire society of the country.

In general, two aspects of assessing the quality of medical services of medical institutions can be distinguished: 
- the technical one directly characterizes an aspect related to the level of professionalism of employees of a medical institution;

- the functional aspect characterizes and reflects the method of receiving visitors to the clinic. This aspect of quality is more difficult to measure because it is based on the subjective opinion of the patient about the nature of the provision of services and his feelings, which form from medical care in general and for each individual.

Data on consumer satisfaction with the medical services provided are presented in Figure 2.

The perception of the quality of medical services by all segments of the population depends not only on the effectiveness of treatment for each and everyone but also on the attitude of the staff of the medical institution to patients.

The quality management system of medical services is a set of organizational and managerial structures and actions that establish, implement, evaluate, analyze and adjust the conditions of the delivery process and the results of medical services to provide the patient with a guaranteed amount of quality medical care.

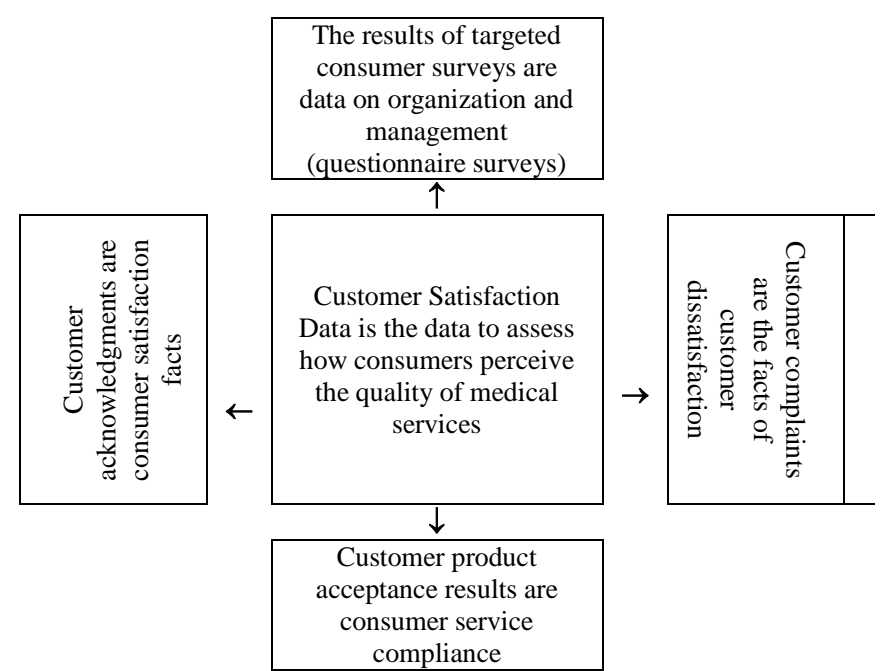

Figure 2 Customer Satisfaction Data on Medical Services

The need to create and develop a quality management system for medical services is determined by the following factors:

- transfer of most of the powers of the Russian Federation in managing social policy to the subjects of the Russian Federation;

- the need to improve the quality of medical services in medical institutions;

- lack of regulatory documents regulating the activities of healthcare organizations and compulsory health insurance to ensure the legitimate interests of all segments of the population in obtaining medical services of the appropriate volume and quality;
- lack of approved criteria for the quality of medical services.

The mechanism for the formation of the state order for the provision of high-tech specialized medical care to the population includes:

- the organization of normative planning (based on federal standards of medical care), carried out both in the next year and in the medium term (2-3 years);

- creating a system of standards of medical care;

- approval of standards of financial expenses for the formation of the state task of high-tech and specialized medical care.

The financial deficit of the state guarantee program limits the availability of adequate medical care, forms a steady tendency for patients to participate in the costs associated with treatment, and to attract funds from other sources of financing. Currently, private medicine accounts for about $15 \%$ of all medical services, and patients are increasingly turning to private clinics. According to experts, the private medicine market will grow by at least $12 \%$ per year. Today, private medicine uses the most advanced medical technologies and modern equipment, and the best professionals in the city collaborate with private clinics.

The main reason for turning to paid medicine is the high quality of the services provided [3].

The development of a quality management system for medical services involves the development of new organizational and methodological approaches to its functioning, based on this, the following areas are formulated:

- improving legislation in the field of quality management of medical care;

- creating the optimal structure of a quality management system for the provision of medical care;

- the formation of a system of norms, rules and standards for managing the quality of medical care.

The concept of the development of healthcare and medical science in the Russian Federation as one of the directions for improving medical services ensures the quality and safety of this assistance through standardization, licensing and certification.

Standards of medical care should serve as the basis for assessing the completeness and quality of the services provided, protecting the rights of the patient [3].

Industry standards for healthcare, which are structural and organizational in their regard, should be based on the use of:

- international classification of diseases;

- individual classifiers of medical diagnostic and functional studies adapted to the international classification of procedures in medicine;

- the state register of medicines approved for use in medical practice and industrial production.

As a result of solving organizational and technical problems, it is necessary to create a standardization service that ensures the organization of the development, approval, adoption and adoption of regulatory documents, monitoring compliance with their requirements. Based on the study of the economic aspects of standardization, 
designed to justify the duration of hospitalization, the justification for the use of medical technologies, especially expensive treatment methods, the stage of the therapeutic diagnostic process and the intensity of treatment.

A standardization system in the field of health should be created as a basis for improving the quality of preventive, therapeutic and diagnostic measures in solving the problems of maintaining and improving the health of all segments of the population [2]. Building a model of a healthcare standardization system in a region methodologically distinguishes three levels of practical implementation of tasks:

- level of organizational and methodological functions;

- level of implementation and enforcement of standards;

- level of qualimetry (measurement) and expert assessment.

To create a single information space for the medical care quality management system, recommendations are given on the advisability of combining high-quality services of health authorities, individual medical and insurance medical organizations, Roszdravnadzor, SIF into a united information network, in which generalized data on the quality of care and solutions to improve its condition.

The creation of a single information space for the quality management system for medical services will allow the creation of a databank on the quality status in medical institutions.

In order to solve the strategic tasks of managing the quality of drug provision at Roszdravnadzor, we propose a mechanism for the phased transition of the pharmaceutical industry to the national rules for the organization of production and quality control of GMP drugs (letter dated 11/06/2007 No. 01-44853/07) [2].

Phased transition includes:

- creation of a regulatory framework for the transition to national Rules for the organization of production and quality control of medicines (GMP standards);

- improving the mechanism of state control;

- increasing the competitiveness of the domestic pharmaceutical industry by harmonizing Russian standards for the development and production of medicines with international requirements;

- stimulation of the development and production of innovative medicines.

The development of a quality management system for medical services to protect human health as one of the core values in the modern world everywhere should be included in the category of priority guidelines for social development [1]. This confirms the need to develop and implement unified organizational and methodological documents in the form of standards/rules within the framework of the concept of customer-oriented medical service.

When using the system of process-oriented management of the quality of medical services in healthcare, an important step is to build a model that allows you to structure the actions of the leadership of a medical institution when achieving key medical and statistical performance indicators and make the process of implementing the basic production functions of a healthcare institution transparent
[5].

Currently, many authors of modern research offer their vision of modeling a process-oriented system for managing the quality of medical services in the healthcare system, adapted directly to healthcare institutions on the basis of theoretical aspects and practical recommendations on this issue [5].

\section{DISCUSSING THE RESULTS}

The process approach is considered key in this set of principles, since it affects most of them. To build a quality management system, a special place is given to step-bystep process management: their determination, description, identification of errors during the implementation of processes and the implementation of measures for their optimization.

By building a process-oriented management system in healthcare institutions, an increase in the speed of servicing consumers of medical services is achieved, minimization of the influence of the human factor, cost reduction, increased productivity and improved quality of medical services through the use of automated information and analytical systems.

In this regard, it is necessary to emphasize that the process orientation of management should be built into the foundation of the existing functional organizational structure of healthcare. This is due to the specifics of medical institutions, in which for the most part functionally-oriented management systems operate, and in combination with a process approach, different facets of managerial activity will be covered, complementing each other and providing the best effective result.

The systematic approach also reflects the need to build management of medical institutions in conjunction with the external and internal environment of the organization. The analysis of the external environment should be carried out taking into account two aspects: the macro level (political and economic situation, environmental situation, demographic indicators and the social sphere) and the micro level (suppliers, consumers, competitors, intermediaries, contact audiences - mass media, funds and others).

With the help of such a comprehensive study of all the influencing factors, provided they are regularly monitored, it is possible to form the most adequate and effective management system of the healthcare institution.

The principle of continuous improvement is based on reducing the number of deficiencies in the provision of medical services, innovative focus, and organization of health care, taking into account new quality standards. This principle is based on Japanese Kaizen technology, thanks to which sustainable economic growth has been achieved in this country. This approach focuses on the development and implementation of the potential of human resources and focuses on customer requirements. 
[2] Prikaz Ministerstva zdravoohraneniya RF No. 240n

\section{FINDINGS (CONCLUSION)}

The development and use of medical innovations are the cornerstones in the activities of healthcare institutions in modern conditions. Without this component, it is impossible to increase the quality of medical services provided to consumers and maintain the competitiveness of a medical institution.

Standardization all over the world and everywhere is an essential condition for the functioning of institutions in all areas of activity, striving to form a quality management system for the medical services provided. Despite the fact that medical services are one of the most difficult objects of standardization, they can also be considered the most significant for the life of society, the economy and the state as a whole, since the values of the main socioeconomic indicators depend on the quality of medical services. In this regard, healthcare institutions, both in Russia and abroad, are now actively using standardization in their professional activities.

The implementation of the principle of a balanced scorecard is necessary to evaluate the results achieved by the medical institution. This principle consists in identifying Key Performance Indicators (KPIs), grouping them, analyzing, interpreting the results and taking measures to establish deviations from standard values.

In accordance with the above principles of the quality management system, it is proposed to build a network model of a process-oriented quality management system for medical services (MS) of an outpatient health care organization.

A key element in the formation of process-oriented quality management of medical services in healthcare institutions is the modeling of business processes, including the identification of business processes, their description, subsequent analysis, and further optimization, as well as the identification of business process owners. The main goal of detailing and further improving business processes is to identify hidden reserves to increase the efficiency of the processes of the primary medical activity of a healthcare institution and the quality of medical services provided to customers.

This proposed model of a process-oriented system for managing the quality of services in healthcare can find application in making managerial decisions by managers in medical institutions of the Russian Federation, regardless of their scalability and form of ownership.

\section{REFERENCES}

[1] Prikaz Ministerstva zdravoohraneniya RF No. 810a ot 31.10 .2013 g. $\ll \mathrm{Ob}$ organizacii raboty po formirovaniyu nezavisimoj ocenki kachestva raboty gosudarstvennyh (municipal'nyh) uchrezhdenij, okazyvayushchih uslugi v sfere zdravoohraneniya». (http://www.consultant.ru - Data obrashcheniya: 30.09.2019) ot 23.04.2013 g. «O poryadke i srokah prohozhdeniya medicinskimi rabotnikami i farmacevticheskimi rabotnikami attestacii dlya polucheniya kvalifikacionnoj kategorii». (http://www.consultant.ru Data obrashcheniya: 30.09.2019)

[3] Aganbegyan A.G. Trevozhnyj zvonochek: v Rossii prekratilos' snizhenie smertnosti naseleniya // Ekonomika zdravoohraneniya. - 2015. T.10. No. 22. S. 63-76.

[4] Strategiya 2020: Novaya model' rosta - novaya social'naya politika [Elektronnyj resurs] Rezhim dostupa:

http://im.kommersant.ru/content/pics/doc/doc1753934.p df

[5] Starodubov V.I., Son I.M., Leonov S.A., Pogonin A.V. Ocenka vliyaniya modernizacii zdravoohraneniya na dinamiku zabolevaemosti vzroslogo naseleniya strany // Menedzher zdravoohraneniya. 2013. No. 5. S. 6-17.

[6] G. Palozzi, S. Brunelli, C. Falivena, Higher sustainability and lower opportunistic behaviour in healthcare: a new framework for performing hospitalbased health technology assessment. Sustainability. 2018. T. 10. No. 10. S. 3550.

[7] I. Bagaeva, I. Ilin, O. Iliashenko, Assessment of the results of the municipal healthcare system reform (Russian experience). V sbornike: E3S Web of Conferences 2019. S. 02086.

[8] G. Ter-Akopov, N. Kosinova, S. Knyazev, Innovation management in the development of regional healthcare. V sbornike: Advances in economics, business and management research. Proceedings of the Volgograd State University International Scientific Conference "Competitive, Sustainable and Safe Development of the Regional Economy" (CSSDRE 2019). 2019. S. 179-183.

[9] N.N. Kosinova, S.P. Sazonov, N.G. Glazkova, Public-private partnership in regional health care modernization: analysis and strategic priorities of its development. V sbornike: Competitive, Sustainable and Secure Development of the Regional Economy: Response to Global Challenges (CSSDRE 2018) Proceedings of the International Scientific Conference. Ser. "Advances in economics, business and management research" 2018. S. 466-470. 
[10] A. Mottaeva, Organizational-and-methodical support of sustainable development strategy in the medical sphere. V sbornike: MATEC Web of Conferences 2018. S. 01045.

[11] E. Laurenza, F. Schiavone, M. Quintano, D. Vrontis, The effect of digital technologies adoption in healthcare industry: a case based analysis. Business Process Management Journal. 2018. T. 24. No. 5. S. 1124-1144.

[12] B. Wong, G.T.S. Ho, E. Tsui, Development of an intelligent e-healthcare system for the domestic care industry. Industrial Management \& Data Systems. 2017. T. 117. No. 7. S. 1426-1445.

[13] V.M. Qin, T. Hone, C. Millett, J.T. Lee, R. Moreno-Serra, B. McPake, R. Atun, The impact of user charges on health outcomes in low-income and middleincome countries: a systematic review. BMJ Global Health. 2018. T. 3. No. 1. S. e001087.

[14] C. Dózsa, K. Jankus, T. Mariann Helter, Structural changes in the Hungarian healthcare system between 2000 and 2017. Value in Health Regional Issues. 2019. T. 19. S. 92-98.

[15] M.M. Ali, A. Medhekar, Healthcare quality of Bangladesh and outbound medical travel to Thailand. Ekonomika regiona. 2018. T. 14. No. 2. S. 575-588.

[16] Z. Sabeeh, S. Syed Mustapha, R. Mohamad, Healthcare knowledge sharing among a community of specialized physicians. Cognition, Technology \& Work. 2018. T. 20. No. 1. S. 105-124. 